\title{
MAIDENS, FILLIES AND THE DEATH OF MEDUSA ON A SEVENTH-CENTURY PITHOS
}

\author{
KATHRYN TOPPER \\ University of Washington*
}

\begin{abstract}
A well-known relief pithos in the Louvre (CA 795) shows Perseus confronting a Gorgon whose human torso terminates in the body of a horse. Her equine features have proven difficult to explain, and earlier discussions of the scene have appealed to lost narratives, seventh-century artistic conventions and broad symbolic associations between Gorgons and horses. Focusing on her combination of equine and maidenly characteristics, this article interprets Medusa's unusual form with reference to a series of ancient Greek metaphors connecting maidens, horses and Gorgons. It argues that recognizing the metaphorical logic of the image allows us to understand Medusa's form as a sympathetic comment upon her death, which has parallels in the sacrifices of maidens in Greek art and literature.
\end{abstract}

The neck of a seventh-century Cycladic pithos presents a striking image of Medusa's death (Fig. 1). ${ }^{1} \quad$ Rendered in low relief with incised details, the scene shows the moment before her beheading, when Perseus holds his sword to her throat. The hero, dressed in a short patterned tunic, a cap and boots, strides forward and grabs a lock of her hair, while turning his head to avoid her gaze. The Gorgon, by contrast, stands still, her arms hanging limply at her sides and her face turned outward. She wears a long, patterned skirt with fabric extending over the length of her lower body, which consists, remarkably, of equine hindquarters extending from a human torso. The two figures are framed by stylized rope-like tendrils on the left and a tall, drooping flower on the right, and a small lizard crawls in the empty space above the Gorgon's body.

What is odd about this scene is not the moment that is depicted - for the beheading would become a favourite subject of Greek artists working in all kinds of media ${ }^{2}-$ but the decision to show Perseus' opponent as part horse. Although Medusa's equine associations are well known, ${ }^{3}$ Centaur-Gorgons are rare in Greek art, appearing only here and on a handful of sixthcentury gems (Fig. 2), ${ }^{4}$ where the mask-like face and the addition of wings suggest a more menacing creature than the one confronting us on the pithos. Most often, however, Medusa appears with the body of a woman, when she is not simply a head, ${ }^{5}$ so it is hardly surprising that her form on the pithos has inspired considerable discussion. Some scholars have sought

\footnotetext{
*ktopper@u.washington.edu. An early version of this article was presented in the 2006-2007 Harvard University Graduate School of Arts and Sciences Word and Image workshop, organized by Andrea Deeker and Julia Faisst. I am grateful to the members of the workshop, especially Melissa Haynes and Natasha Bershadsky, for their comments and criticisms. For advice on various written and oral versions of this paper, I thank Gloria Ferrari Pinney, Laurie Kilker, Anita Nikkanen and the audience at the 2009 meeting of the Archaeological Institute of America, as well as the anonymous $J H S$ readers and Editor Angus Bowie. Finally, I am very grateful to Laurialan Reitzammer for reading drafts and for her help with the Hecuba.

${ }^{1}$ Paris, Musée du Louvre CA 795; RP B2. A similar scene seems to have appeared on another pithos now in the Louvre, but only Perseus remains (Paris, Musée du
}

Louvre CA 937; $R P$ B3). For descriptions of both pieces, see De Ridder (1898) 448-58.

${ }^{2}$ See, for example, the images collected in LIMC 4, s.v. Gorgo, Gorgones ('Die Enthauptung der Medusa'); LIMC 7, s.v. Perseus ('Perseus beheads Medusa'); Schauenburg (1960).

${ }^{3}$ On these, see especially Vernant (1991) 116, 11820, 124-25, 129, 131-33; Tsiafakis (2003) 87-88; Marconi (2007) 144, 148-50; Langdon (2008) 114.

${ }^{4}$ London, British Museum WA 103307; Boardman (1968) 27, no. 32. See the nearly identical design on the gem published in Boardman (1968) 27, no. 31 (collection unknown) and the discussion of the GorgonHorse Group in Boardman (1968) 27-39.

${ }^{5}$ Very rarely, the Gorgon appears with the lower body of another kind of animal, such as a snake, panther or sea monster; see LIMC 4, s.v. Gorgo, Gorgones ('Andere Mischwesen'). 
explanations in previously unknown narratives, suggesting that Medusa was given the form of a horse to please her lover Poseidon, who was worshipped as Hippios in Boeotia. ${ }^{6}$ Others appeal to artistic convention, arguing that the scene shows an unparalleled interpretation of the birth of Pegasos, or that the quadruped body was a generic marker of monstrosity in Orientalizing art. ${ }^{7}$ Still others have interpreted the equine Medusa along more broadly symbolic lines, noting a general association between Gorgons and horses ${ }^{8}$ or suggesting that, because Medusa gave birth to both a horse and a man, she would naturally appear with the characteristics of both creatures. ${ }^{9}$

Most of these interpretations are probably valid to some degree ${ }^{10}$ - as Jean-Pierre Vernant has noted, 'the imagistic associations between the Gorgon and the horse provide a surplus, even an overflow of meaning' 11 - yet I believe it is possible to arrive at a more detailed understanding of the Gorgon's equine associations on the pithos. In particular, I propose that her hybrid form makes sense when read against a series of ancient metaphors linking maidens, horses and Gorgons. ${ }^{12}$ In what follows, therefore, I explore the possibility that the logic underlying Medusa's form on the pithos is neither narrative nor a matter of artistic convention, but metaphorical. By recognizing the network of metaphors connecting these three types of creatures, I will show, we can see that Medusa's representation as an equine maiden betrays an ambivalence about Perseus' actions, which are cast as the slaughter of a creature that - like the sacrificial maidens who appear in later tragedies - is more rightfully a candidate for domestication. ${ }^{13}$

Understanding the connection between Gorgons and horses requires us first to recognize certain features the former share with more typical maidens of Greek myth. The connection is apparent in both art and literature, which define these monsters as perversions of the mythical groups that provided the paradigm for maidens' choruses. ${ }^{14}$ In his classic study of these choruses, Claude Calame demonstrated that such groups in their standard form consisted of maidens connected by age, geography and sometimes familial associations, with one girl standing out

${ }^{6}$ Howe (1954) 213-14. One problem with this suggestion is that in stressing the local character of the worship of Poseidon Hippios it relies too heavily on the Boeotian origin of the pithos, which many scholars now believe to have been produced in the Cyclades (Ahlberg-Cornell (1992) 113; Tsiafakis (2003) 87; Hurwit (2006) 123-24). On the connection of the image to the myth of Medusa and Poseidon, see also Malten (1914) 184; Hampe (1936) 58-61; Langdon (2008) 114. Burkert ((1985) 138, 222) and Papachatzis ((1987) 109-15) consider Poseidon's equine aspects.

7 Ahlberg-Cornell (1992) 114; Snodgrass (1998) 84-88. On the latter possibility, cf. Woodford (2003) 208-09. Carpenter ((1991) 104-05) suggests that in the absence of models for the Gorgon's appearance, the early artist was left to his own devices in deciding how to convey her monstrosity; cf. Howe (1954) 213-14; Ebbinghaus (2005) 63.

${ }^{8}$ Vernant (1991) 124-25.

${ }^{9}$ Fittschen (1969) 128; Ebbinghaus (2005) 63.

${ }^{10}$ Less satisfactory is Frothingham's suggestion that Medusa's equine body expressed an affinity with the Mistress of Animals and proved her connection to an ancient Mediterranean mother goddess ((1911) 37377). Although the Gorgon seems to be related in some fashion to Artemis as Potnia Thêrôn, scholars have convincingly refuted the hypothesis that the original divinity in Greece was a prehistoric mother goddess
(Georgoudi (1992); Loraux (1992)), so it is difficult to see Medusa as a survival of any such figure.

${ }^{11}$ Vernant (1991) 116.

${ }^{12}$ Langdon, in a study that became available after the first draft of this article had been submitted, observes this connection but does not discuss it in detail ((2008) 114).

13 I have not attempted to relate the scene to the shape or function of the pithos, in part because of continued disagreement over the primary function (or functions) of relief pithoi - a problem compounded by the likelihood that many pithoi were used in more than one way prior to deposition. For a summary of hypotheses regarding the uses of relief pithoi, see Ebbinghaus (2005) 52-58 (where it is argued that most relief pithoi were created for the storage of food and wine, rather than for the funerary uses to which some were later put). In general, my understanding of the relationship between shape and iconography follows that of Ferrari, who argues that in the absence of a more solid understanding of the principles governing the connection between shape and imagery on Greek painted vases, it is inadvisable to attempt ad hoc explanations for individual pieces ((2002) 9). The same caution is warranted in the interpretation of the relief pithoi, especially given the uncertainty surrounding their intended functions.

14 Topper (2007); for the Gorgons' maidenly qualities, see also Langdon (2008) 110-14. 


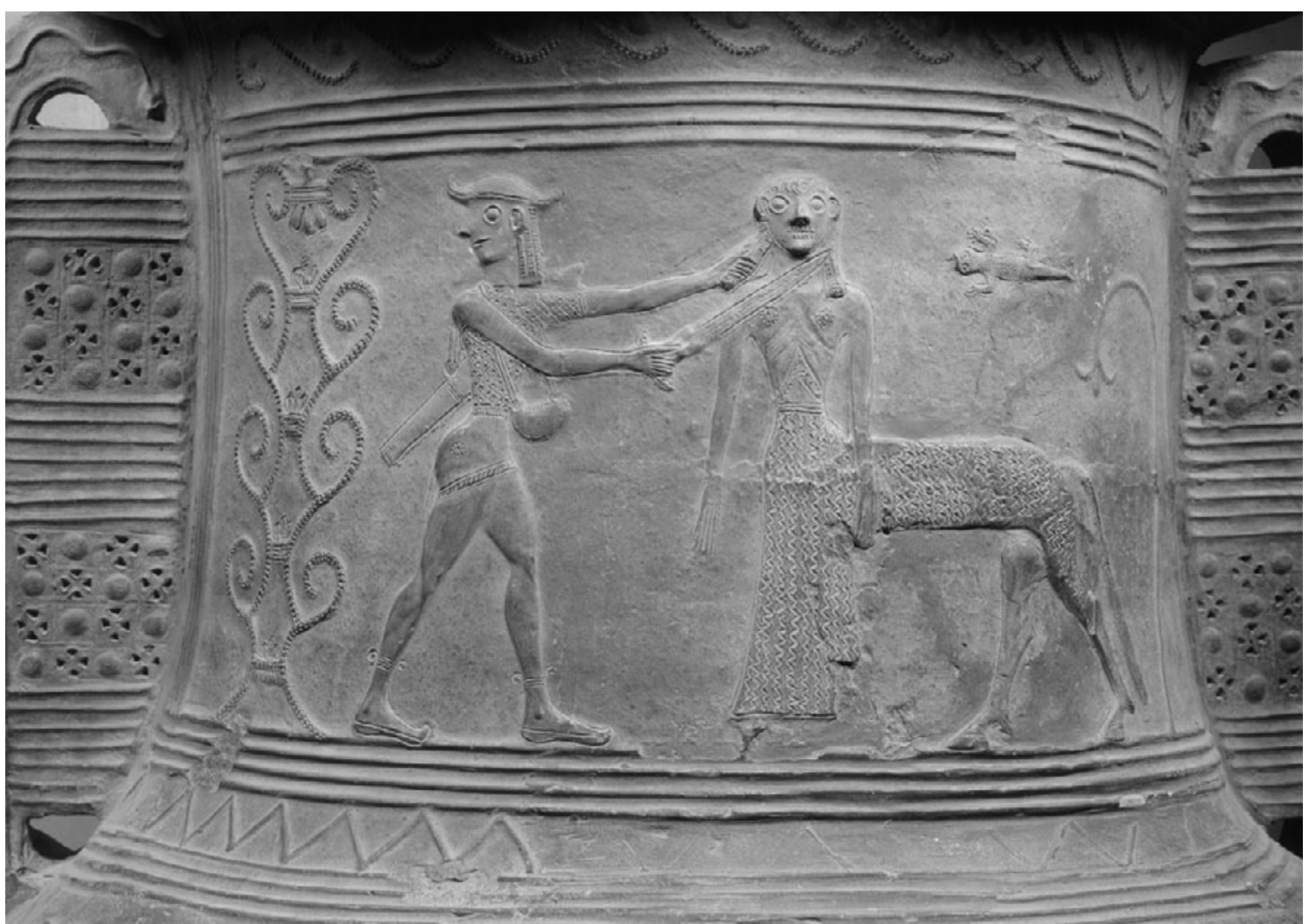

Fig. 1. Perseus killing Medusa. Cycladic relief pithos (neck detail) (Paris, Musée du Louvre CA 795; photo credit: Réunion des Musées Nationaux/Art Resource NY)

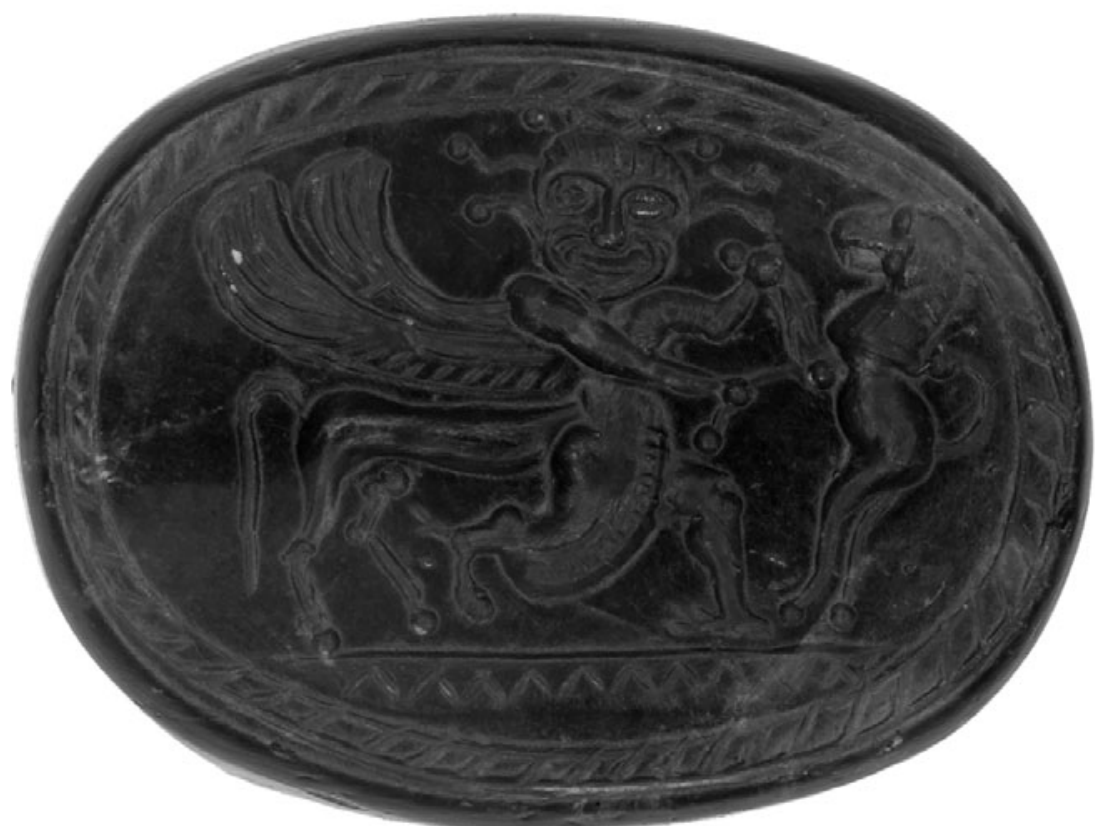

Fig. 2. Winged Gorgon with horse's body confronting lion. Amethyst scarab (London, British Museum WA 103307; (C) The Trustees of The British Museum) 
from the rest. That girl, hailed as the loveliest among her peers, is abducted and raped by a hero or god, in a pattern familiar from the stories of Persephone, Thetis, Helen and numerous other mythical girls. ${ }^{15}$ Calame has traced this configuration of maidens through Greek literature and ritual practice, while studies of Greek art have shown that in the imagery, too, these maidens and their abductions assume a highly formulaic appearance. ${ }^{16}$ Although the iconography of abduction has been most thoroughly explored in black- and red-figure Athenian vase painting, Susan Langdon has recently shown that the theme of the maiden's abduction from a circle of her peers was familiar to Greek artists as early as the Geometric period. ${ }^{17}$

I have argued elsewhere that both art and literature present Medusa and her sisters as a distorted version of the maiden chorus. Like Thetis, Helen and their companions, the Gorgons travel as a collective, and one - Medusa - is singled out for male attention, first by Poseidon and then by Perseus. ${ }^{18}$ The chief differences lie in the fact that Medusa is killed, rather than raped, by the hero - although the death has sexual overtones insofar as it results in the birth of Pegasos and Chrysaor ${ }^{19}$ - as well as in the fact that many versions of the story present the Gorgons as monsters, rather than the sweet maidens we would expect in a typical rape narrative. Medusa's death, in other words, is a maiden's abduction that has taken a turn for the grotesque, where the emphasis is on mortality and monstrosity rather than erôs. It is within the framework of the mythical abduction that we may understand accounts such as the one in the Theogony (270-81), where the Gorgons are clearly maidens, or those that single out Medusa for her beauty, like

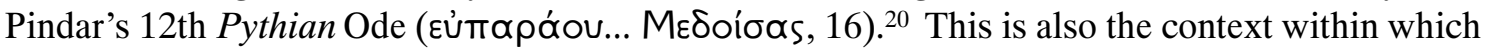
images that adopt the formula for erotic abduction to show Perseus' flight from the Gorgons make sense, especially where the Gorgons are shown as beautiful maidens. ${ }^{21}$

Medusa's identity as a maiden matters to our understanding of the scene on the pithos (Fig. 1) because the Greeks commonly represented sexually innocent girls through the figure of the horse. The metaphor of the maiden as a horse was widespread and pervasive, and its appearance in Alcman's seventh-century Partheneion (45-59) leaves no doubt about its antiquity.22 Together with metaphors that associated maidens with other animals, such as fawns, the definition of the unmarried girl as a horse cast her as a figure both desirable and in need of domestication. ${ }^{23}$ The erotic quality of the equine metaphor is especially apparent in Anacreon's address to a girl he calls a 'Thracian filly' ( $\pi \tilde{\omega} \lambda \varepsilon \Theta \rho \eta \Theta^{\prime} i n, P M G$ 417), who shuns the speaker's attempts to restrain her with reins or bridle, preferring instead to play in the meadow where she grazes ( $\nu \tilde{v} \nu \delta \dot{\varepsilon} \lambda \varepsilon \varepsilon\lrcorner \mu \tilde{\omega} \nu$ ás

15 Calame (1997) 19-88. His argument is anticipated by Webster (1954) 11-12.

16 Kaempf-Dimitriadou (1979); Zeitlin (1986); Sourvinou-Inwood (1987a); (1987b); Stewart (1995); Frontisi-Ducroux (1996); Osborne (1996); Ferrari (2002) 43-47.

${ }^{17}$ Langdon (2008) 197-233.

18 Topper (2007) 82-89. Vermeule seems to have been thinking along similar lines when she described the Gorgons as characters in 'a Cinderella story, three sisters with the interesting one marked out for love by the sea-king Poseidon' ((1979) 139); see also the comments of Langdon (2008) 112.

${ }^{19}$ On the sexual dimension of Medusa's death, $c f$. Vermeule (1979) 139; Langdon (2008) 112, 208.

20 On the Hesiodic Gorgons as maidens, $c f$. Vermeule (1979) 136; Langdon (2008) 112. Pindar's

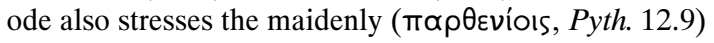
character of the Gorgon sisters.

21 Strasbourg, Institut d' Archéologie Classique
1574; $A R V^{2}$ 1361.2. Taranto, Museo Nazionale; $A R V^{2}$ 1361.1. Ferrara, Museo Nazionale di Spina 2512; $A R V^{2}$ 1206.2; Para. 463; $A d d .^{2}$ 344. London, British Museum F 500; LCS 255.194.

22 On Alcman's horse imagery, see most recently Ferrari (2008) 72-77, 95-96.

${ }^{23}$ For a partial list of references to the maiden as a fawn or filly, see Henrichs (1996) 70, n.38, with discussion on 36-38. On metaphors that link maidens with horses or other wild animals, see also GhironBistagne (1985); Reeder (1995) 299-300; Calame (1997) 191, 238-44; Edmunds (1997); Power (2000) 78-80; Griffith (2006b) 309-11, 324-26; Ferrari (2008) 72-77, 95-96; Langdon (2008) especially 114, 162-65, 173-74. Vernant notes the connection between young girls and horses in the ancient Greek imagination, but his discussion of the Gorgon's equine qualities focuses on the horse's wild and violent side rather than the appealing qualities that made it suitable for erotic metaphors ((1991) especially 120-21). 


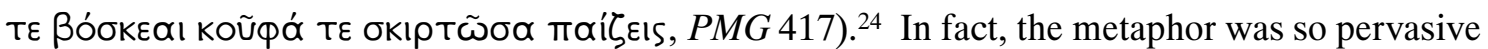
that it was incorporated into the language of marriage, which was cast as the taming of the bride even when no animal was specified. An early, vivid instance of the metaphor occurs in Thetis'

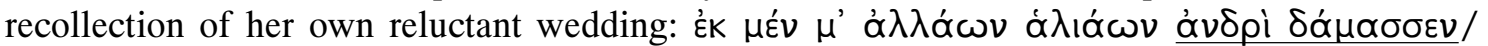

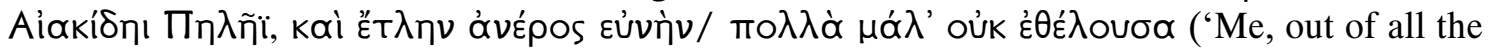
other daughters of the sea, he yoked to a man, to Peleus son of Aeacus, and I endured a mortal's bed, though resisting greatly', Hom. Il. 18.432-34).

With these points in mind, let us look again at the scene on the relief pithos (Fig. 1). It is striking that with the exception of her equine hind parts, Medusa is all maiden, with none of the monstrous features found on many other Archaic Gorgons, such as the snaky hair or the wings of the Gorgon on the gem in London (Fig. 2). On the pithos, Medusa's gaze confronts us directly, and small incisions in her mouth suggest bared teeth, but her features are otherwise like those of her human attacker. The two figures share the same round eyes, triangular nose and high-set ears, and both have their hair arranged in tame, shoulder-length plaits. The flower behind the Gorgon further highlights her girlish qualities, calling to mind the flowery meadows from which mythical maidens are abducted and in which she herself was raped by Poseidon. ${ }^{25}$ A certain wildness is suggested by her frontal gaze and bared teeth, not to mention her equine form. But while she is clearly shown as something more than human, her monstrosity does not depend on the grotesque facial distortions that it does elsewhere - what seems to be at work instead is a particular interpretation of the idea that maidens are like horses. The effect is analogous to one we encounter in later representations of Thetis' abduction, where lions and snakes crawl around the goddess and her mortal attacker (Fig. 3). ${ }^{26}$ Although their presence is obviously required by the narrative, the animals also take on a metaphorical role, insofar as they show us the wild creatures that Thetis, as a maiden, resembles. What distinguishes the images of Thetis from that of the horse-Medusa is the way that the former is kept visually distinct from the animals she resembles - that is, the metaphor of the maiden as a wild animal is expressed through the placement of animals alongside the struggling goddess. On the pithos (Fig. 1), by contrast, the animal and the maiden are grotesquely blended, and here the Gorgon's monstrosity depends on an unusually literal interpretation of the metaphor. ${ }^{27}$

Having recognized the maiden-as-filly metaphor as a structuring principle of this image, we can begin to move towards a more nuanced understanding of the scene as a whole. In particular, I suggest, we can start to see the ways in which the decision to portray Medusa as a maiden who is also a horse brings to the fore a deep ambivalence about the actions of her killer. ${ }^{28}$ The position of Perseus' sword, poised to penetrate the Gorgon's throat, is especially revealing in this regard. Nicole Loraux has shown that to die by a wound to the neck was a particularly female fate in ancient Greek thought, and death by bloodshed from the neck (derê or, less commonly, auchên)

24 Scholars disagree as to whether the poem's addressee is a courtesan or simply an innocent girl (Kurke (1999) 183-84; Griffith (2006b) 325-26); however, as Kurke notes, the force of the metaphor derives from its success in evoking the image of a modest virgin even if the woman in question is not one ((1999) 184, n.15).

25 On the meadows in which Medusa and other maidens are raped, see Vernant (1991) 123; Power (2000) 79 (with no mention of Medusa); Topper (2007) 86; Langdon (2008) 208. Riccioni invokes the principle of horror vacui to explain the background elements (including the flower) on the pithos ((1960) 149), but the large amount of empty space in this scene suggests that another explanation is desirable. In fact, Caskey notes that this pithos is exceptional for its use of 'filling ornament', which does not appear on most others of its type ((1976) 31). The flowers on the Protoattic amphora in Eleusis further suggest that the flowery landscape was significant to the artistic conception of Medusa's death (Archaeological Museum 2630). The lizard is harder to account for, although see Hurwit (2006) 123-24.

${ }^{26}$ Berlin, Antikensammlung F 2279; $A R V^{2}$ 115.2, 1626; Para. 332; Add. ${ }^{2} 174$.

27 This blending is consistent with what Vernant calls the Gorgon's 'telescoping of what is normally kept separate' ((1991) 137).

${ }^{28}$ I have previously explored this ambivalence in Athenian and south Italian vase painting (Topper (2007)). 
was the mark of the maiden, a figure who is repeatedly represented as the object of men's violent advances. ${ }^{29}$ Loraux is concerned primarily with tragic representations of female death, but as she observes, the tragedians were working within a well-established discourse, not defining a new one. In fact, their fixation on the neck of the virgin is consistent with a larger pattern, most explicit in ancient gynaecological texts but also evident elsewhere, of conflating the neck (and sometimes the mouth) with the vagina. This metaphor equated blood shed from the neck with hymeneal blood and helps to account for the peculiarly maidenly character of deaths resulting from a cut to the throat. ${ }^{30}$ It is evident that the same metaphor operates in representations of Medusa, who is repeatedly shown giving birth to Pegasos and Chrysaor through her neck after Perseus has cut off her head. ${ }^{31}$

The Gorgon's mode of death, then, likens her to other maidens, such as Iphigeneia and Polyxena, who die by wounds to the throat, and the position of Perseus' sword on the pithos calls attention to the connection. The association with these mythical girls gives Medusa's equine characteristics added significance, for, as Loraux has observed, maidens who die by wounds to the throat in Greek myth are typically victims of sacrifice, and animal metaphors figure prominently in representations of their deaths. ${ }^{32}$ In most versions of Iphigeneia's sacrifice, Artemis saves the girl's life by substituting an animal in her place, and images of Polyxena's death show the Trojan maid lifted in the manner of a sacrificial animal as her throat is slit. On a sixth-century Tyrrhenian amphora, she is hoisted up by three men in military garb, while a fourth man, Neoptolemos, drives a knife into her throat and blood from the wound pours onto the altar (Fig. $4) ;{ }^{33}$ she is subjected to similar treatment on one of the long sides of a late Archaic sarcophagus from a tumulus at Gümüşçay. ${ }^{34}$ In fact, this iconographic formula may have been current as early as the seventh century, if Emily Vermeule and others are correct to see a maiden's sacrifice on a fragmentary Protoattic krater that shows a skirted figure lifted by a line of men in a composition strongly reminiscent of the sixth-century images. ${ }^{35}$

The tragedians, too, used animal metaphors to describe sacrificial maidens, comparing them to goats (chimaira, Aesch. Ag. 232), heifers (moschos, Eur. IT 359; IA 1080-83) and - most significant for our interpretation of the pithos - horses. The final metaphor may be explicit, as when the chorus of the Hecuba calls the sacrificial Polyxena a pôlos (Eur. Hec. 142), ${ }^{36}$ or it may only be implied. The latter is true of the description of Iphigeneia's sacrifice in the Agamemnon: although Aeschylus likens the girl to a chimaira when her father's men are instructed to lift her over the altar (Ag. 232), the restraints placed over her mouth are called chalinoi - a word used for bits or bridles (238) - in a figure of speech that invites the audience to envision the unfortunate girl as a sacrificial horse. Loraux has persuasively argued that the description of a sacrificial maiden as a horse, a creature that should be tamed but not killed by its rider, betrayed an unease about the slaughter of someone whose proper fate was the domestication that would come with marriage. For Polyxena, Iphigeneia and others in their position, she concludes, 'the sacrifice is tragically ironic in that it resembles, all too closely, a marriage'. ${ }^{37}$

\footnotetext{
${ }^{29}$ While men in Greek literature and art may also die from neck wounds, Loraux has shown that they die from wounds all over the body, whereas women's fatal wounds are typically confined to the neck ((1987) 50-56).

${ }_{30}$ Loraux (1987) especially 31, 41, 61. On the conflation of neck and vagina or cervix, see also Hanson (1990) 317, 326-29; King (1998) 75-98 (who explores the sacrificial associations of menstrual blood).

${ }^{31}$ On the confusion between the upper and lower bodily registers in representations of Medusa, see Vernant (1991) 137.

${ }^{32}$ Loraux (1987) 31-48.
}

33 London, British Museum 1897.7-27.2; $A B V$ 97.27, 683; Para. 37; $A d d^{2}$ 26. Van Straten (1995) surveys the iconography of animal sacrifice.

34 Çanakkale, Archaeological Museum; Sevinç (1996) 256-57, figs 9-10.

${ }^{35}$ Boston, Museum of Fine Arts 6.67; Vermeule and Chapman (1971) figs 1-4. See also Vermeule (1979) 185-86; Morris (1984) 68-69; Ahlberg-Cornell (1992) 52-53.

${ }^{36}$ For pôlos as a word for both a young person and a young horse, see Vernant (1991) 120.

${ }^{37}$ Loraux (1987) 34-37, especially 37. 


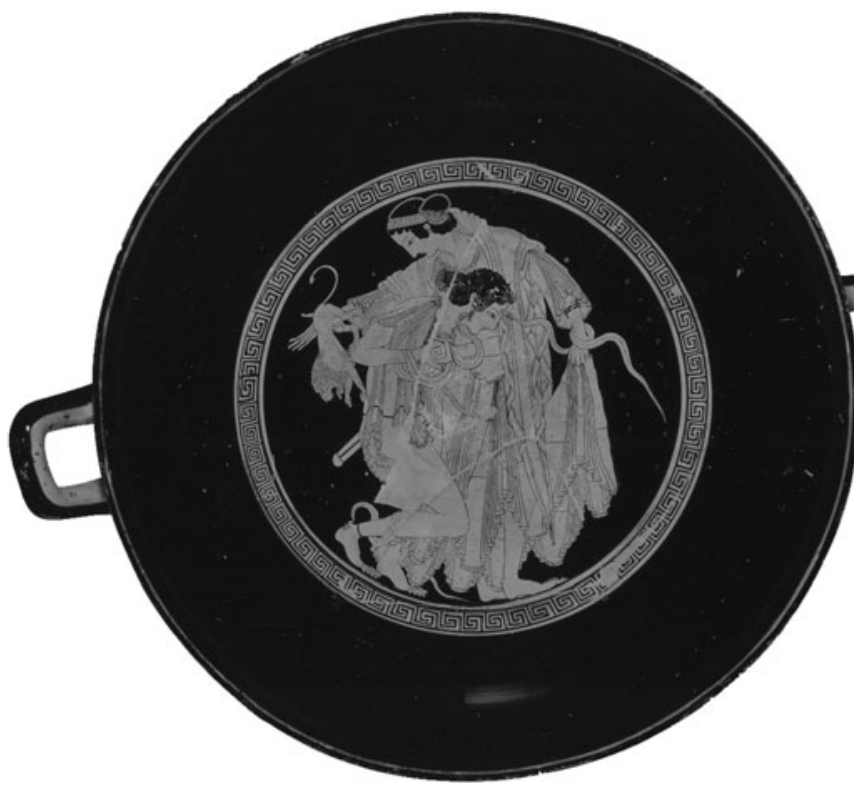

Fig. 3. Peleus wrestling Thetis. Attic red-figure kylix tondo, Peithinos (Berlin, Antikensammlung F 2279; $A_{R V}^{2}$ 115.2, 1626; Para. 332; Add. ${ }^{2}$ 174; photo credit: Bildarchiv Preussischer Kulturbesitz/Art Resource NY)

Fig. 4. Sacrifice of Polyxena. Black-figure Tyrrhenian amphora, Timiades Painter (London, British Museum GR 1897.7-27.2; ABV 97.27, 683; Para. 37; Add. ${ }^{2}$ 26; (C) The Trustees of The British Museum/Art Resource NY)

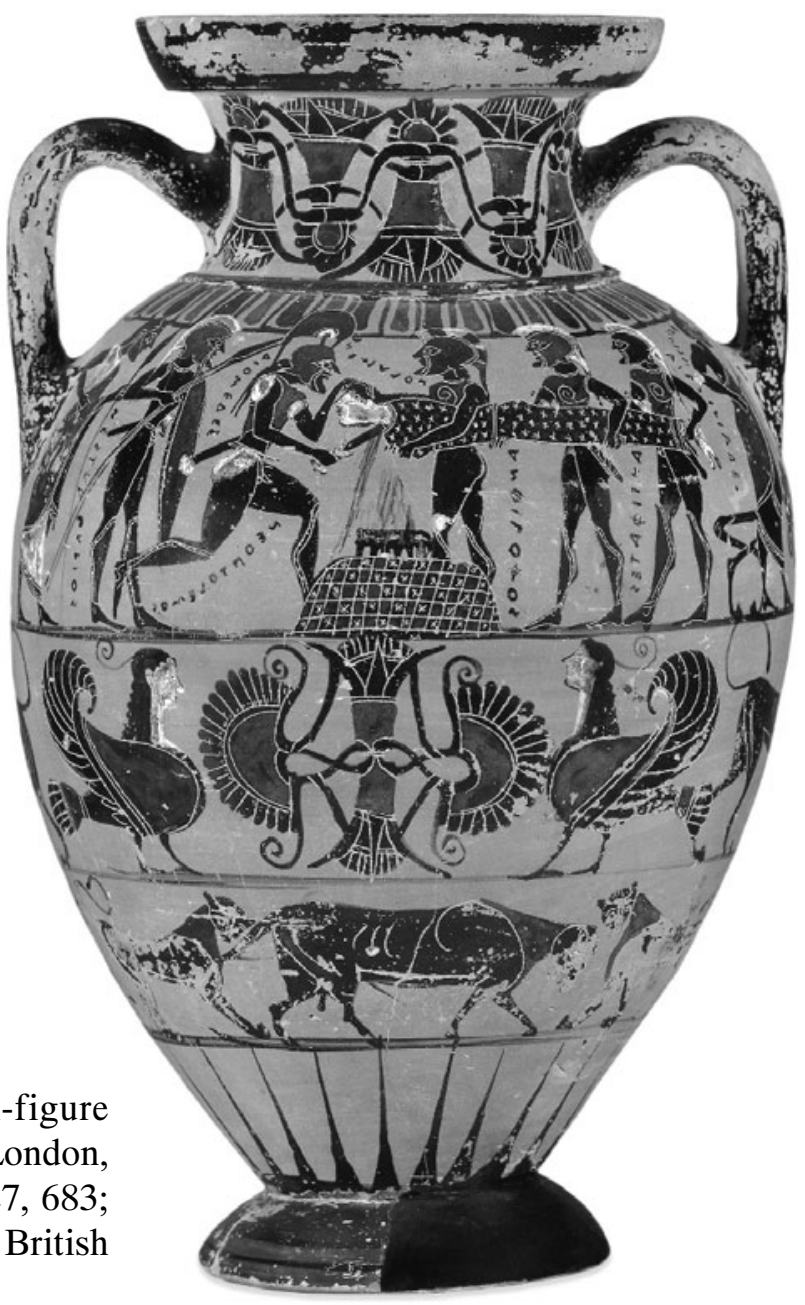


Although the tragedies examined by Loraux postdate the scene on the relief pithos by approximately two centuries, there is good reason to believe that the pithos and the plays drew upon the same nexus of metaphors involving girls, horses and sacrifice. The metaphor of the maiden as a horse seems to have been a fixture of Greek conceptions of gender by the late Geometric period, and the analogy between the marriage of the maiden and the domestication of the horse is drawn repeatedly in Geometric art. Pointing to the frequent juxtaposition of horse-leaders and female dancers on Argive Geometric kraters, Langdon observes that 'the recurrent image of taming evokes a language of husbandry that is not meant for the horse alone' ${ }^{38}$ In the seventh century, the metaphor is explicit in Alcman's Partheneion (45-59), which compares its chorus of maidens to various breeds of horses. Both the literary and the archaeological evidence, moreover, suggest that these early ideas about the proper relationship between horses and men were consistent with beliefs held in later centuries, a conclusion that also applies to ideas about the sacrifice of horses. ${ }^{39}$ Archaeological evidence indicates that horse sacrifices had long since disappeared from most of the Greek world by the time the pithos under discussion was created and, for the most part, these sacrifices are represented in Greek literature only under extraordinary circumstances. ${ }^{40}$ It is likely, in other words, that original viewers of the pithos would have shared later tragic audiences' misgivings about the sacrifice of a horse-maiden.

As a maiden who is like an untamed filly, Medusa appears on the pithos as a rightful candidate for marriage, not death, and by highlighting both her equine and her maidenly characteristics the image presents the hero's actions as an outrage akin to the sacrifice of Iphigeneia or Polyxena. His grip on the Gorgon's hair, a gesture that also appears in scenes of Polyxena's sacrifice, underlines this point. As Mark Griffith has noted, access to the hair of a woman or a horse implied a special level of intimacy: 'for aristocratic women and finely bred horses alike, the hair on their heads and necks was their crowning glory, an ostentatious sexual symbol, artfully and proudly displayed to all, yet untouchable except by their authorized husband/rider or their specially designated "maids/grooms". ${ }^{41}$ The image of Perseus slaughtering a horse thus violently disrupts the prescribed relationship between man and beast - and between man and woman - and the sacrificial associations of the maiden with the sword at her throat magnify the sense that something is very wrong with this scene. While it is difficult to say exactly why the artist took such care to emphasize the pathos of the Gorgon's death, a similar note of sympathy is evident in the

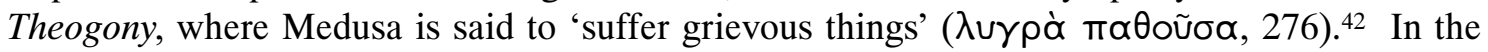
contemporary visual arts, the emphasis on the victim's suffering has a close relative in the scenes on a famous relief pithos from Mykonos that depicts the sack of Troy in horrifying detail, omitting neither the abuse of the city's women nor the slaughter of its children. ${ }^{43}$ More fragmentary pithoi, which show fallen warriors devoured by birds, seem designed to evoke a similar response. ${ }^{44}$ The emphasis on the pathetic in the image of the Centaur-Medusa, then, is consistent not only with other accounts of her death, but also with a more general contemporary artistic interest in the portrayal of suffering.

38 Langdon (2008) 164; see also 173-74. The gendered connotations of the relationship between horse and rider in all periods are underscored by the infrequency with which Greek women are represented as riders (Griffith (2006a) 202).

${ }^{39}$ For ancient Greek attitudes towards horses, see Bodson (1978) 151-61; Ghiron-Bistagne (1985); Edmunds (1997); Griffith (2006a); (2006b); Rothwell (2007) 38-41; Ferrari (2008) 72-77, 95-96.

${ }^{40}$ On horse sacrifices in Greek literature and the archaeological record, see Farnell (1907) 20; Henderson (1987) 92-93; Kosmetatou (1993); Reese (1995); Edmunds
(1997); Griffith (2006a) 199; Rothwell (2007) 39.

${ }^{41}$ Griffith (2006b) 310.

42 The conception of the Gorgon as a pitiable figure is also apparent in later representations, particularly those that show her sleeping when Perseus kills her (Topper (2007) 90-94).

${ }_{43}$ Mykonos, Museum 2240. On this piece, see especially Ervin (1963); Caskey (1976) 28-29; Ebbinghaus (2005).

44 For example, Athens, National Archaeological Museum 2495; RP T2; Caskey (1976) 27-28. Also Eretria, Museum 16620-1; Ebbinghaus (2005) pl. 3c. 
Examining the Centaur-Medusa's death through the lens of metaphor has provided a glimpse into the concerns about maidenhood, sexuality and violence that contributed to the forms the Gorgon assumed in the ancient Greek imagination. ${ }^{45}$ It has also revealed certain parallels between Medusa's death and the maiden sacrifices of tragedy, with which it shares a metaphorical logic. With this point in mind, I would like to end by looking more closely at one tragic maiden whose death especially resembles Medusa's, the Polyxena of Euripides' Hecuba. Polyxena, whom the chorus calls a filly early in the play ( $\pi \tilde{\omega} \lambda \circ \nu, 142)$, goes to her death in a manner reminiscent of the image on the pithos, and if Euripides and the anonymous seventh-century artist were drawing on a shared conception of the maiden sacrifice despite their chronological separation, then it is possible that each of these representations of a maiden's death can illuminate aspects of the other.

In a consideration of the Hecuba, Loraux has shown that for all its consistency with other maiden sacrifices, Polyxena's death possesses a distinctly masculine character. Refusing to plead

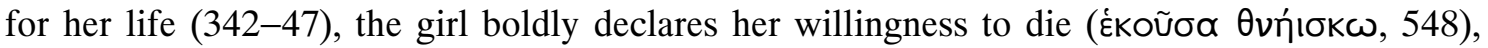
going so far as to open her peplos to offer Neoptolemos her breast before falling to her knees (561-65). With this gesture, Loraux suggests, the princess displays a warrior's courage, since it is the warrior - not the maiden - who typically dies by a blow to the sternon. ${ }^{46}$ It is remarkable how closely the image conjured by the messenger's description resembles the one on the pithos, where another bare-breasted maiden submits to death by a hero's sword - and even more than Polyxena, Medusa is a maiden with unmistakably masculine qualities. ${ }^{47}$ In fact, as Loraux points out, Polyxena's masculine display is ultimately effaced both by the soldiers' enthrallment with the sight of her feminine body and by Neoptolemos' choice of her throat as the site for his fatal blow. When she finally falls to the ground, she is careful to guard from the men's eyes what is unsuitable for them to see (569-70), as she is 'reclaimed at the last moment by femininity'. ${ }^{48}$

Loraux attributes the triumph of the feminine in Polyxena's death to a fundamental conservatism within tragedy: 'whatever freedom the tragic discourse of the Greeks offered to women, it did not allow them ultimately to transgress the frontier that divided and opposed the sexes. Tragedy certainly does transgress and mix things up - this is its rule, its nature - but never to the point of irrevocably overturning the civic order of values' ${ }^{49}$ It is here that Euripides' Polyxena and the Centaur-Medusa depart from one another most dramatically - on the pithos, the sight of a wild animal-maiden who retains a masculine control of the gaze even in her moment of defeat is not diminished by a graceful death that conforms to the requirements of civilized femininity. Taken together, the two representations seem to suggest that it is possible to meet death with unmitigated boldness or as a civilized maiden - but not both. For all the challenges the scene on the pithos presents to our understanding of Perseus' conquest, then, the terms by which it defines the maiden turn out to be surprisingly conventional.

Up until this point, I have used the image on the pithos and the scene from the Hecuba to cast light on each other on the premise that they rely on the same metaphors to construct the sacrificial maiden, although I have not claimed any direct relationship between the two. Is it possible, however, that the idea of the Gorgon as a sacrificial maiden was available to Euripides when he had his herald narrate Polyxena's death? Some suggestion that the sacrificial associations of Medusa's death persisted beyond the seventh century comes from a fourth-century Kerch pelike that depicts her beheading in a fashion extraordinarily consistent with the description of Polyxena's death in the Hecuba. ${ }^{50}$ Here a remarkably human Gorgon falls to her knees, her robe

\footnotetext{
45 This is not to say that every image of an equine Gorgon was concerned with the pathos of the victim; a different explanation is probably desirable for, for example, the Gorgon-Horse gems (Fig. 2).

${ }^{46}$ Loraux (1987) 58-60.

${ }^{47}$ Vernant (1991) 137.
}

${ }^{48}$ Loraux (1987) 61.

${ }^{49}$ Loraux (1987) 60.

50 St Petersburg, State Hermitage Museum St. 1918; LIMC 4 (1988) 313, no. 304, s.v. Gorgo, Gorgones (I. Krauskopf). 
slipping down to expose her breasts, as Perseus drives his sword into her neck. Although it is difficult to draw firm conclusions from two images separated by several centuries, they at least raise the possibility that there was a continuous tradition of associating Medusa with other sacrificial maidens throughout the Archaic and Classical periods, and that this association informed more traditional representations of the maiden sacrifice.

It is now clear, in any case, that the form given to Medusa on the pithos turns her body into the site of two transgressions. One transgression is the hero's: by driving his sword into the throat of a horse-maiden, Perseus assumes the questionable role of a sacrificiant charged with slaughtering a creature intended for domestication. At the same time, the Gorgon herself is cast as a victim whose bold display crosses the boundaries of what civilized femininity will tolerate; though pitiable, she remains distinctly threatening. Without subordinating one to the other, the image puts before our eyes both her threatening wildness and her maidenly vulnerability, and in doing so creates an unexpected space in which to contemplate the maiden's sacrifice.

\section{Bibliography}

Ahlberg-Cornell, G. (1992) Myth and Epos in Early Greek Art: Representation and Interpretation (Studies in Mediterranean Archaeology 100) (Jonsered)

Boardman, J. (1968) Archaic Greek Gems: Schools and Artists in the Sixth and Early Fifth Centuries BC (London)

Bodson, L. (1978) 'IEPA ZSIA: Contribution à l'étude de la place de l'animal dans la religion grecque ancienne (Brussels)

Burkert, W. (tr. J. Raffan) (1985) Greek Religion (Cambridge MA)

Calame, C. (tr. D. Collins and J. Orion) (1997) Choruses of Young Women in Ancient Greece: Their Morphology, Religious Role, and Social Function (Lanham)

Carpenter, T.H. (1991) Art and Myth in Ancient Greece (London)

Caskey, M.E. (1976) 'Notes on relief pithoi of the Teneian-Boiotian group', AJA 80, 19-41

De Ridder, A. (1898) 'Les amphores béotiennes à reliefs', $B C H$ 22, 439-71, 497-519

Ebbinghaus, S. (2005) 'Protector of the city, or the art of storage in early Greece', JHS 125, 51-72

Edmunds, A.L. (1997) 'The horse and the maiden (Aeschines 1.182 etc.): an urban legend in ancient Athens', with appendices by R. Palmer. http://www.rci.rutgers.edu/ edmunds/HorseMaidenTOC.html

Ervin, M. (1963) 'A relief pithos from Mykonos', ADelt 18 A', 37-75

Farnell, L.R. (1907) The Cults of the Greek States (Oxford)

Ferrari, G. (2002) Figures of Speech: Men and Maidens in Ancient Greece (Chicago)

- (2008) Alcman and the Cosmos of Sparta (Chicago)

Fittschen, K. (1969) Untersuchungen zum Beginn der Sagensarstellungen bei den Griechen (Berlin)

Frontisi-Ducroux, F. (tr. N. Kline) (1996) 'Eros, desire, and the gaze', in N.B. Kampen (ed), Sexuality in Ancient Art: Near East, Egypt, Greece, and Italy (Cambridge) 81-100

Frothingham, A.L. (1911) 'Medusa, Apollo, and the Great Mother', AJA 15, 349-77

Georgoudi, S. (tr. A. Goldhammer) (1992) 'Creating a myth of matriarchy', in P. Schmitt Pantel (ed), A History of Women: From Ancient Goddesses to Christian Saints (Cambridge MA) 449-63

Ghiron-Bistagne, P. (1985) 'Le cheval et la jeune fille, ou De la virginité chez les anciens grecs', Pallas 30, 105-21

Griffith, M. (2006a) 'Horsepower and donkeywork: equids and the ancient Greek imagination (Part 1)', CPh 101, 186-246

- (2006b) 'Horsepower and donkeywork: equids and the ancient Greek imagination (Part 2)', CPh 101, $307-58$

Hampe, R. (1936) Frühe griechische Sagenbilder in Böotien (Athens)

Hanson, A.E. (1990) 'The medical writers' woman', in D.M. Halperin, J.J. Winkler and F.I. Zeitlin (eds), Before Sexuality: The Construction of Erotic Experience in the Ancient Greek World (Princeton) 30937

Henderson, J. (1987) Aristophanes: Lysistrata (Oxford) 
Henrichs, A. (1996) 'Warum soll ich denn tanzen?' Dionysisches im Chor der griechischen Tragödie (Stuttgart)

Howe, T.P. (1954) 'The origin and function of the Gorgon-head', AJA 58, 209-21

Hurwit, J.M. (2006) 'Lizards, lions, and the uncanny in early Greek art', Hesperia 75, 121-36

Kaempf-Dimitriadou, S. (1979) Die Liebe der Götter in der attischen Kunst des 5. Jahrhunderts v. Chr. (Bern)

King, H. (1998) Hippocrates' Woman: Reading the Female Body in Ancient Greece (London)

Kosmetatou, E. (1993) 'Horse sacrifices in Greece and Cyprus', JPR 7, 31-41

Kurke, L. (1999) Coins, Bodies, Games, and Gold: The Politics of Meaning in Archaic Greece (Princeton)

Langdon, S. (2008) Art and Identity in Dark Age Greece, 1100-700 B.C.E. (Cambridge)

Loraux, N. (tr. A. Forster) (1987) Tragic Ways of Killing a Woman (Cambridge MA)

— (tr. A. Goldhammer) (1992) 'What is a goddess?', in P. Schmitt Pantel (ed), A History of Women: From Ancient Goddesses to Christian Saints (Cambridge MA) 11-44

Malten, L. (1914) 'Das Pferd im Totenglauben', JDAI 29, 179-255

Marconi, C. (2007) Temple Decoration and Cultural Identity in the Archaic Greek World: The Metopes of Selinus (Cambridge)

Morris, S.P. (1984) The Black and White Style: Athens and Aigina in the Orientalizing Period (New Haven)

Osborne, R. (1996) 'Desiring women on Athenian pottery', in N.B. Kampen (ed), Sexuality in Ancient Art: Near East, Egypt, Greece, and Italy (Cambridge) 65-80

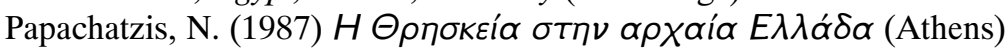

Power, T. (2000) 'The parthenoi of Bacchylides 13', HSPh 100, 67-81

Reeder, E.D. (ed) (1995) Pandora: Women in Classical Greece (Princeton)

Reese, D.S. (1995) 'Equid sacrifices/burials in Greece and Cyprus: an addendum', JPR 9, 35-42

Riccioni, G. (1960) 'Origine e sviluppo del gorgoneion e del mito della Gorgone-Medusa nell'arte Greca', RIA 9, 127-206

$R P=$ Schäfer, J. (1957) Studien zu den griechischen Reliefpithoi ses 8.-6. Jahrhunderts v. Chr. aus Kreta, Rhodos, Tenos und Boiotien (Kallmünz)

Rothwell, K.S. Jr (2007) Nature, Culture, and the Origins of Greek Comedy: A Study of Animal Choruses (Cambridge)

Schauenburg, K. (1960) Perseus in der Kunst des Altertums (Bonn)

Sevinç, N. (1996) 'A new sarcophagus of Polyxena from the salvage excavations at Gümüşçay', Studia Troica 6, 251-64

Snodgrass, A. (1998) Homer and the Artists: Text and Picture in Early Greek Art (Cambridge)

Sourvinou-Inwood, C. (1987a) 'Menace and pursuit: differentiation and the creation of meaning', in C. Bérard, C. Bron and A. Pomari (eds), Images et société en Grèce ancienne: L'iconographie comme méthode d'analyse (Lausanne) 41-58

- (1987b) 'A series of erotic pursuits: images and meanings', JHS 107, 131-53

Stewart, A. (1995) 'Rape?', in E.D. Reeder (ed), Pandora: Women in Classical Greece (Princeton) 74-90

Topper, K. (2007) 'Perseus, the maiden Medusa, and the imagery of abduction', Hesperia 76, 73-105

Tsiafakis, D. (2003) “" $\Pi Е \wedge \Omega P A$ ”: fabulous creatures and/or demons of death?', in J.M. Padgett (ed), The Centaur's Smile: The Human Animal in Early Greek Art (New Haven) 73-104

Van Straten, F.T. (1995) Hierà Kalá: Images of Animal Sacrifice in Archaic and Classical Greece (Leiden)

Vermeule, E.T. (1979) Aspects of Death in Early Greek Art and Poetry (Berkeley)

Vermeule, E.T. and Chapman, S. (1971) 'A Protoattic human sacrifice?', AJA 75, 285-93

Vernant, J.-P. (1991) 'Death in the eyes: Gorgo, figure of the Other', in F.I. Zeitlin (ed), Mortals and Immortals: Collected Essays (Princeton) 111-38

Webster, T.B.L. (1954) 'Personification as a mode of Greek thought', JWI 17, 10-21

Woodford, S. (2003) Images of Myths in Classical Antiquity (Cambridge)

Zeitlin, F.I. (1986) 'Configurations of rape in Greek myth', in S. Tomaselli and R. Porter (eds), Rape (Oxford) $122-51$ 
